\title{
Medical Literature on Novel Coronavirus (COVID-19) Pandemic: A Scientometric Study with Special Reference to WHO COVID- 19 \\ Database
}

Chandima Wadasinghe ${ }^{1}$

\begin{abstract}
Since the emergence of the novel Coronavirus disease from Wuhan, China, in early December 2019, scientists every where in the world have focused on this infection to find a way to deal with it. Due to the rapid growth in the literature on this disease, the WHO took the initiative to collate the emerging publications and created "WHO COVID-19 Database". A scientometric study was conducted to better understand the nature of medical literature on COVID-19 included in the WHO COVID19 Database, and this article aims to provide an analysis of the coverage of those publications focusing on the twelve months, from December 2019 to November 2020. A total of 35,791 full-text research articles on Coronavirus infections has been published across the world. These publications were originated from 57 countries, indicating the international spread of COVID-19 research. The USA was the largest contributor with 12,989 articles, followed by UK and Netherlands. All the publications mentioned above are written in 15 different languages where English has become the dominant language out of all those
\end{abstract}

\footnotetext{
${ }^{1}$ Senior Assistant Librarian, Postgraduate Institute of Medicine, University of Colombo

Email: chandima@pgim.cmb.ac.lk (iD https://orcid.org/0000-0003-2384-1489
} 
languages with $93.25 \%$. According to the findings, the co-authorship network of 3 authors Eric J. Rubin, Lindsey R. Baden and Stephen Morrissey has made the highest contribution with 34 papers published in the New England Journal of Medicine (N Engl J Med). The journal with the highest number of publications on COVID-19 research was the International Journal of Environmental Research and Public Health (Int. J. Environ. Res. Public Health - online). The classification of study type reveals that the maximum number of articles are published on risk factors. This study showed that core journals publishing COVID-19 research are scattered among journals, closely conforming to Bradford's Law of scattering. The Lotka's Law on authorship productivity has been tested to confirm the law's applicability to the present dataset. According to the test, there is a variation of author productivity between the observed percentage and expected percentage of authors as in Lotka's Law. This study will help the research community to get the required information for their research. Further, the information in this paper will encourage the researchers in finding more facts on COVID-19.

Keywords: Novel Coronavirus (COVID-19) Infections, Medical Literature, WHO COVID-19 Database, Scientometrics, Bradford's Law, Lotka's Law 


\section{Introduction}

The outbreak of the novel Coronavirus Disease 2019 (COVID-19) with human to human transmission originated in Wuhan, China, in early December 2019, is an ongoing global epidemic incident (Huang et al., 2019). The current outbreak of Coronavirus Disease 2019 (COVID-19) has posed many challenges in the world. To control the ongoing pandemic, the scientific communities have boosted their researches and development activities. It is a highly transmittable and pathogenic viral infection spread from the Wuhan city of China to other countries, inside and outside Asia (Medical News Today, 2020). The World Health Organization (WHO) temporarily called the new virus 2019 Novel Coronavirus (2019-nCoV) and then officially termed this infectious disease as Coronavirus Disease 2019 (COVID-19) on $12^{\text {th }}$ February 2020 and declared this as a pandemic (World Health Organization, 2020a). COVID-19 is a disease caused by a new strain of Coronavirus. ' $C O^{\prime}$ stands for corona, ' $V I$ ' for the virus, and ' $D$ ' for the disease. This disease was formally referred to as '2019 novel Coronavirus' or '2019-nCoV', (World Health Organization, 2020c). The virus spread rapidly world wide, exerting influence on 220 countries and caused a catastrophe in almost all the spheres of life, including public health, daily living, and the current world economy. Sixty-three million seven hundred nineteen thousand two hundred thirteen confirmed cases of the virus reported so far, and it has taken nearly 1,482,084 lives. More than 45,043,555 people have recovered to date November 2020 (Worldometer, 2020).

Medical literature written on the current pandemic is vital to combat this novel Coronavirus. Researchers world wide are engaged in identifying the cause, clinical features and developing possible vaccines 
for COVID-19. As a result, rapid growth in publishing scholarly literature on this matter can be seen worldwide. The present surge in publications resulted in the need to generate a systematic database of all COVID-19 related articles to get the full advantage of research. The leader in world health, the World Health Organization (WHO), created one of the largest databases of COVID-19 research related databases (World Health Organization, 2020b). This study aims to identify and analyse the trends in the global research on COVID-19 based on the WHO COVID-19 database by applying scientometric tools. Using scientometric tools, one can measure the various parameters related to publications based on quantitative analysis.

The study of the quantitative aspects of the process of science as a communication system is called scientometrics. Scientometrics, also known as "science of science," is a popular statistical method to critically analyse scientific literature in a particular field (Hood \& Wilson, 2001). The scientometric studies provide various metrics to assess the scholarly literature (Tran et al., 2019). Scientometrics is the investigation of science as the development of information process, and "scientometric studies broadly constitute quantitative analyses of scientific literature to reveal the latest developments in various fields and the patterns of the geographical distribution of science and scientific productivity of individual nations" (Nalimov \& Mulchenk, 1969, p. 2).

This study helps people to understand the nature of the medical literature on Coronavirus infections and relationship within the research output of the COVID-19 pandemic and will help overcome the problems to some extent. The findings of the study will be important for library professionals, medical professionals, and medical students who will be 
using the literature on Coronavirus infections during their research. Hence, this kind of study will significantly impact the researchers interested in Coronavirus infections, outline the research trends, and determine the most relevant research areas for future endeavours.

\section{Objectives of the Study}

Extracting data from clinical research related to COVID-19 will be crucial for improving and developing the diagnosis, treatment, and preventive strategies against this viral infection. Many epidemiological and clinical pieces of evidence have emerged, and a significant number of researches have been published as well. Therefore, the aim of this study is to analyse and investigate the nature and publication pattern of COVID-19 related publications in the WHO COVID-19 database using scientometrics indicators.

\section{Literature Review}

It is evident that during December 2019 and November 2020, COVID-19 related medical literature has upsurged unprecedentedly.

Kambhampati et al. (2020) conducted a research study on exploring the PubMed database with 6,831 papers. Out of these papers, six thousand four hundred and fifteen papers were in the English language and published in 1,430 journals. The British Medical Journal (BMJ) has published 252 papers, the highest number of papers in a single journal. Dehghanbanadaki et al. (2020) has researched on the papers indexed in the Scopus Database using the keyword of COVID-19, covering the period from $1^{\text {st }}$ December 2019 to $1^{\text {st }}$ April 2020. In the country list, China came first with 348 papers, followed by the USA with 160 papers. The Lancet and BMJ have published the highest number of 
publications. Darsono et al. (2020) collected bibliometric data from December 2019 to March 2020 from the Scopus Database. A total number of 1,475 publications had focused on information and knowledge sharing among the international COVID-19 researchers. In 2019 a total of $801(45.3 \%)$ papers were published, while $674(45.7 \%)$ papers were in 2020. The study found 11 types of publications. The Viruses journal with 74 papers was the leading journal, then The Lancet with 50 papers and the Journal of Virology with 39 papers. According to the study, China has produced 386 papers, which was the highest as a country. The highest number of papers from an organization was reported from the University of Hong Kong, producing 44 papers. Tao et al. (2020) conducted a study on Coronavirus research and extracted data from 9,760 publications from the Web of Science database from 2000 to 2020. The Journal of Virology bears the top place with 885 publications. The USA was the leading country that has published 959 publications, and the University of Hong Kong has become the highest producing institution with 411 publications. Lou et al. (2020) have searched the PubMed database with the keyword COVID-19 and extracted the data from 183 publications published during $14^{\text {th }}$ January to $29^{\text {th }}$ February 2020 . The result showed that the authors were from 20 different countries. The Journal of Medical Virology published the highest number, 25 papers, and English was the dominant language, followed by Chinese.

This study results reflect the global research output and tremendous growth of publications on COVID-19. The scientometric study of medical literature in Coronavirus infections is limited, and no comprehensive study of the scientometric study of the medical literature of publications in the field of Coronavirus infections is available. This 
investigation aimed to bridge this gap and provide a guide in evaluating the Coronavirus infections literature.

\section{Methodology}

This particular study has adopted a descriptive research approach through scientometric study, because of its nature as an exploratory investigation to describe the quantity and productivity of global medical literature in COVID-19 infection. This study is based on World Health Organization (WHO) global research database on Coronavirus disease (COVID-19) made available through the WHO official website. In this study, research articles were identified by searching for the keyword 'Coronavirus infections'as the Medical Subject Headings (MeSH). The total number of 35,791 publications was extracted in full-text articles of journals covering the period of December 2019 to November 2020. The retrieved data have been fed into MS Excel and loaded in SPSS for analysis.

\section{Bradford Law of Scattering}

Bradford Law of scattering explains how the literature on a particular subject is scattered or distributed in journals. Bradford (1948) formulated his law as follows:

When we arrange scientific journals in order of decreasing productivity of articles on a given subject, in that case, they may be divided into a nucleus of periodicals more particularly devoted to the subject, and several groups or zones containing the same number of articles as the nucleus. The number of divisions in the nucleus and succeeding zones will be as $1: n: n^{2}$, where ' $n$ ' is a multiplier. (Brookes, 1985, p. 177) 


$$
\text { 1: } n: n^{2}, \text { where ' } n \text { ' is a multiplier }
$$

\section{Lotka's Law}

Lotka's Law is one of the bibliometrics laws, which deals with the authors' frequency of publication in any given field. The researchers measured research productivity using different parameters from time to time. "Lotka's Law of scientific productivity (author's productivity in a subject) is a law of scientometric. One can use it to map authors' productivity patterns in a subject. The following equation better articulate the Lotka's Law" (Lotka, 1926, p. 318):

\begin{tabular}{|ll|}
\multicolumn{1}{c|}{$\boldsymbol{x}^{n} \boldsymbol{y}=\boldsymbol{C}$} \\
$x$ & $=' x$ ' is the number of articles published \\
$y$ & $=$ ' $y$ ' is the number of authors having a frequency of $x$ \\
& number of articles \\
$\mathrm{C}$ & $={ }^{\prime} C^{\prime}$ is a constant \\
$n$ & $=' n$ ' is an exponent
\end{tabular}

The law describes that the number (of authors) making ' $n$ ' contributions is about $1 / \mathrm{n}^{2}$ of those making one. The number of authors that make a single contribution is of about $60 \%$. It means that $60 \%$ of the authors produce one publication; $15 \%\left(1 / 2^{2} \times 60\right)$ produces two publications, $7 \%\left(1 / 3^{2} \times 60\right)$ produces three publications, and so on. The law is a generalised approach that maps the authorship far better than a rigid law that varies from one field to another. Still, it gives an expanded prospect to know authors' productivity pattern in a discipline (Coile, 1978). 
Here ' $x$ ' represents the number of articles published $(1,2,3,4 \ldots)$; ' $y$ ' is the number of authors having the frequency ' $x$ ' number of articles; ' $n$ ' is an exponential constant for a particular set of data, and ' $\mathrm{C}$ ' is a constant. When $\mathrm{n}=2$ is used for a data set, in the case that ' $\mathrm{C}=0.6079$ ', the law is called 'Inverse-square law of scientific productivity', in this case. The value of 'n' differs from data set to data set. (Askew, 2008, p. 9)

\section{Results and Discussion}

During December 2019 to November 2020, a total of 35,791 fulltext articles have been published on Coronavirus infections in the form of full-text research articles. During a short span of twelve months, many documents have been published as COVID-19 being a new infectious disease, and scientists are keen to study and report on this new disease that has affected almost the whole world. The 35,791 research articles appeared in 3,861 journals and have been authored by 74,773 authors. Data on the bibliographical records were extracted from the online version of the WHO COVID-19 database about Coronavirus (COVID19) infections research publications.

\section{Contribution of Publications on Coronavirus (COVID-19) Infections}

Each country, scientists, and organizations have supported the collaborative distribution of their knowledge with research to find the solution to the problem through international collaborations. Using the search term "Coronavirus infections", a total of 35,791 publications have been retrieved from WHO COVID-19 database. Out of 25 databases, CNKI_Lanzhou - Lanzhou University/CNKI, COVIDWHO, ELSEVIER, LILACS LILACS (America), MEDLINE, PubMed, WPRIM WPRIM 
(Western Pacific) were found with the results related to Coronavirus infections. The research productivity on Coronavirus infections covered in WHO COVID-19 database for the period from December 2019 to November 2020 is shown in Table 1.

\section{Table 1}

Month-wise Publications on Coronavirus (COVID-19) Infections

\begin{tabular}{lcc}
\hline \multicolumn{1}{c}{ Month } & Number of articles & $\%$ \\
\hline December 2019 & 20 & 0.06 \\
January 2020 & 359 & 1.00 \\
February 2020 & 1107 & 3.09 \\
March 2020 & 4170 & 11.65 \\
April 2020 & 5932 & 16.57 \\
May 2020 & 6467 & 18.07 \\
June 2020 & 5068 & 14.16 \\
July 2020 & 4234 & 11.83 \\
August 2020 & 3523 & 9.84 \\
September 2020 & 2426 & 6.78 \\
October 2020 & 1058 & 2.96 \\
November 2020 & 1427 & 3.99 \\
\hline Total & 35,791 & 100 \\
\hline
\end{tabular}

Table 1 and Figure 1 analyses the publications on Coronavirus infections published in different journals in the WHO COVID-19 database for a time frame from December 2019 to November 2020. The total was 35,791 articles. This analysis showed that the most significant number of publications were in May with 6,467 (18.07\%) publications, 
April with 5,932 (16.57\%) and June with 5,068 (14.16\%) publications, each being published and ranked $1^{\text {st }}, 2^{\text {nd }}$ and $3^{\text {rd }}$ place in the period of study. The growth of publications on Coronavirus infections during the period under the study was found to be uneven but slightly in an increasing nature from January to May 2020.

\section{Figure 1}

Month-wise Publications on Coronavirus (COVID-19) Infections

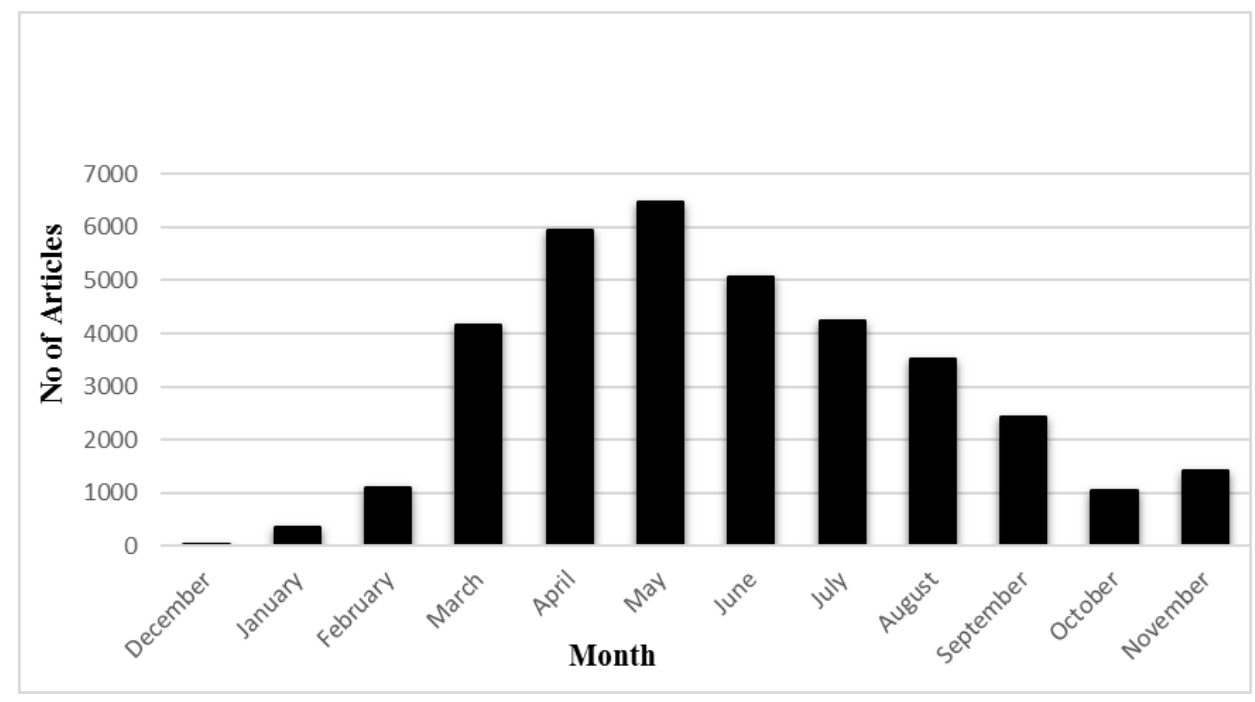

\section{Distribution of Journals}

Research on Coronavirus infections has been published in several sources. In the study, highly productive journals were identified, and it was found that these journals collectively contributed immensely. Out of the 15,796 journals in the database, there are 35,791 articles in 3,861 journals. Table 2 shows the distribution of articles in these journals.

It is visible that 3,820 out of 3,861 journals have published less than 100 articles so that less than 25 articles in 3,567 journals, between 26 to 50 articles in 177 journals, between 51 to 75 articles in 51 and 75 to 
99 articles in 25 journals. There are 30 journals that have between 101200 articles. From the remaining 11 journals, 6 journals have articles between 201-300, 4 journals with the number of articles between 301400 and only one journal with 401-500 articles during the study period.

\section{Table 2}

Distribution of Articles in Journals

\begin{tabular}{|c|c|c|}
\hline Article range & Number of journals & $\%$ \\
\hline $100>$ & 3820 & 98.94 \\
\hline $101-200$ & 30 & 0.78 \\
\hline $201-300$ & 6 & 0.16 \\
\hline $301-400$ & 4 & 0.10 \\
\hline $401-500$ & 1 & 0.03 \\
\hline Total & 3,861 & 100 \\
\hline
\end{tabular}

\section{Distribution of Journals in Research on COVID-19 Based on Bradford Law of Scattering}

Bradford's Law of scattering describes a quantitative relationship between papers and journals in which they publish. It further explains that only a small number of core journals will supply the nucleus of papers on a given topic which accounts for a substantial percentage (1/3) of the articles. There is a second more extensive group of journals that accounts for another one-third of the articles. Consequently, the next group contains the remaining one-third of the articles.

Bradford's Law of scatters discusses the mathematical distribution (scattering) of documents on a given subject. Growth in articles on a subject requires an increase in the number of journals. The numbers of 
the journals to produce nearly equal numbers of articles are roughly in proportion 1: $n: n^{2}$, where ' $n$ ' is called the Bradford multiplier. Bradford's law states that a small core of journals, For example, journals that have as many papers on a given subject and as a much larger number of journals ' $n$ ', which again has as many papers on the subject as ' ${ }^{21}$ journals (Rao, 1998).

Bradford's Law of scattering explains the quantitative connection between journals. The journals are divided in to three equal zones: onethird of articles in each zone after arranging in descending order of productivity. Hence, applying the above expression to this study, 35791 articles are divided into three groups, as presented in Table 3.

\section{Table 3}

Distribution of Articles to Journals According to Bradford's Law

\begin{tabular}{ccccc}
\hline Zone & Number of journals & $\%$ & Records (articles) & $\%$ \\
\hline Zone 1 & 110 & 2.85 & 11928 & 33.33 \\
Zone 2 & 473 & 12.25 & 11925 & 33.32 \\
Zone 3 & 3278 & 84.90 & 11938 & 33.35 \\
\hline Total & 3,861 & 100 & 35,791 & 100 \\
\hline
\end{tabular}

According to Bradford's Law of scattering, one-third of the total of 35791 is considered.

Total number of records(Articles) considered $=35791$

Approximate Number of articles in a Zone $=35791 \times \frac{1}{3}$

$$
=11930.33
$$

Total number of articles in first 110 journals $=11928$ 
When it comes to the $111^{\text {th }}$ journal it exceeds the number 11930.33, therefore 11928 articles in 110 journals is the Zone 1.

The next 473 journals from the $111^{\text {th }}$ journal sum up to 1,1925 articles. Therefore 1,1925 articles in 473 journals is the Zone 2.

The remaining 3,278 journals sum up to 11,938 articles and it is in Zone 3.

Percentage of the journals in each zone $=\frac{\text { Number of journals in the zone }}{\text { Total number of journals }} \times 100$ Percentage of the articles in each zone $=\frac{\text { Number of articlesinthezone }}{\text { Totalnumber of articles }} \times 100$ Bradford's expression (1: $n: n^{2}$, where ' $n$ ' is a multiplier) is calculated as follows:

$\frac{\text { number of joumals in } Z \text { one } 1}{\text { number of joumals in rone } 1} \frac{\text { number of joumals in } Z \text { one } 2}{\text { number of joumals in rone } 1}=\frac{\text { number of joumbis in rone } 3}{\text { number of joumals in rone } 1}$

$1: \frac{473}{110}: \frac{3278}{110}=1: 4.3: 29.8 \cong 1: 5: 30$

In the context of present literature on Coronavirus infections, it is found that 110 journals constitute the first zone has 11,928 articles, the next zone with 473 journals has 1,1925 articles, and a much larger group of 3,278 journals have 1,1938 articles. When analysing the data, it is found that the literature on Coronavirus infections does not follow this rule, and the numbers of journals in three zones are seen roughly in the proportion 1:5:30, which closely fit Bradford's expression (1: $\left.n: n^{2}\right)$. 


\section{Journals with more than 100 Publications}

The ranking of the journals (with articles greater than 100) by its number of articles on Coronavirus infections is given in Table 4. The top 41 journals out of 110 core journals publishing such research are shown in Table 4. The highest number of publications in the International Journal of Environmental Research and Public Health (online) is a peerreviewed open access scientific journal published by Multi disciplinary Digital Publishing Institute in Switzerland.

The second highest is The Lancet, while PLoS One and BMJ both have the same number of articles. These are the top three leading journals that have published the maximum number of articles.

\section{Geographical Distribution of Publications}

The global COVID-19 research output is originated from 57 countries during the study period and contributed 35791 full-text articles. Table 5 presents the research publications on Coronavirus infections by the top 25 most productive countries from December 2019 to November 2020. The United States of America is leading in the list with the number one position by contributing $(12,989)$, the highest number of publications.

According to the WHO regions, the top 25 countries include 12 European countries, five regions of the Americas countries, six Western Pacific Region countries, one South-East Asia Region country and one Eastern Mediterranean region (Figure 2). The United States is leading the list being the highest productive $(12,983)$. The other productive countries were the United Kingdom with 9,462, followed by the Netherlands with 2,678 articles, and Singapore was the lowest with 73 articles. 


\section{Table 4}

List of Sources with more than 100 Publications

\begin{tabular}{lcclcc}
\hline \multicolumn{1}{c}{ Journal } & $\begin{array}{c}\text { Number } \\
\text { of articles }\end{array}$ & $\%$ & \multicolumn{1}{c}{ Journal } & $\begin{array}{c}\text { Number } \\
\text { of articles }\end{array}$ & $\%$ \\
\hline $\begin{array}{l}\text { Int J Environ Res Public Health } \\
\text { (Online) }\end{array}$ & 433 & 1.21 & Travel Med Infect Dis & 137 & 0.38 \\
The Lancet & 376 & 1.05 & MMWR Morb Mortal Wkly Rep & 133 & 0.37 \\
PLoS One & 364 & 1.02 & Eur Respir J & 130 & 0.36 \\
BMJ & 364 & 1.02 & Am J Trop Med Hyg & 127 & 0.35 \\
JAMA & 309 & 0.86 & Lancet Respir Med & 120 & 0.34 \\
Nature & 281 & 0.79 & Am J Respir Crit Care Med & 120 & 0.34 \\
Crit Care & 268 & 0.75 & Eur Rev Med Pharmacol Sci & 114 & 0.32 \\
N Engl J Med & 255 & 0.71 & Ann Intern Med & 114 & 0.32 \\
Int J Infect Dis & 250 & 0.70 & J Glob Health & 114 & 0.32 \\
J Infect & 245 & 0.68 & Acta Biomed & 114 & 0.32
\end{tabular}




\begin{tabular}{lccccc}
\hline \multicolumn{1}{c}{ Journal } & $\begin{array}{c}\text { Number } \\
\text { of articles }\end{array}$ & $\%$ & & Journal & $\begin{array}{c}\text { Number } \\
\text { of articles }\end{array}$ \\
\hline Science & 230 & 0.64 & Anesth Analg & 113 & 0.32 \\
Sci Total Environ & 196 & 0.55 & Euro surveill & 111 & 0.31 \\
J Med Internet Res & 176 & 0.49 & CMAJ & 108 & 0.30 \\
Lancet Infect Dis & 153 & 0.43 & Emerg Infect Dis & 108 & 0.30 \\
Medicine (Baltimore) & 148 & 0.41 & Trials & 108 & 0.30 \\
Front Immunol & 146 & 0.41 & World Neurosurg & 106 & 0.30 \\
J Am Acad Dermatol & 144 & 0.40 & Brain Behav Immun & 104 & 0.29 \\
Diabetes Metab Syndr & 144 & 0.40 & JAMA Netw Open & 104 & 0.29 \\
World Neurosurg & 143 & 0.40 & Chest & 101 & 0.28 \\
Med Hypotheses & 142 & 0.40 & Indian J Ophthalmol & 101 & 0.28 \\
Psychol Trauma & 141 & 0.39 & & & \\
\hline
\end{tabular}




\section{Table 5}

WHO Region-wise Distribution of Publications

\begin{tabular}{|c|c|c|c|c|}
\hline $\begin{array}{c}\text { Country } \\
\text { code }\end{array}$ & $\begin{array}{c}\text { Number of } \\
\text { articles }\end{array}$ & $\%$ & Country & WHO region \\
\hline US & 12,989 & 36.29 & $\begin{array}{l}\text { United States } \\
\text { of America }\end{array}$ & Region of the America \\
\hline GB & 9,462 & 26.44 & $\begin{array}{l}\text { United } \\
\text { Kingdom }\end{array}$ & European Region \\
\hline NL & 2,678 & 7.48 & Netherlands & European Region \\
\hline $\mathrm{CH}$ & 1,297 & 3.62 & Switzerland & European Region \\
\hline $\mathrm{DE}$ & 1,113 & 3.11 & Germany & European Region \\
\hline $\mathrm{CA}$ & 792 & 2.21 & Canada & $\begin{array}{l}\text { Region of the } \\
\text { Americas }\end{array}$ \\
\hline IT & 713 & 1.99 & Italy & European Region \\
\hline ES & 605 & 1.69 & Spain & European Region \\
\hline BR & 587 & 1.64 & Brazil & $\begin{array}{l}\text { Region of the } \\
\text { Americas }\end{array}$ \\
\hline FR & 547 & 1.53 & France & European Region \\
\hline $\mathrm{CN}$ & 538 & 1.50 & China & Western Pacific Region \\
\hline $\mathrm{AU}$ & 443 & 1.24 & Australia & Western Pacific Region \\
\hline IE & 389 & 1.09 & Ireland & European Region \\
\hline IN & 353 & 0.99 & India & $\begin{array}{l}\text { South-East Asia } \\
\text { Region }\end{array}$ \\
\hline $\mathrm{KR}$ & 239 & 0.67 & Korea & Western Pacific Region \\
\hline PL & 173 & 0.48 & Poland & European Region \\
\hline JP & 156 & 0.44 & Japan & Western Pacific Region \\
\hline
\end{tabular}




\begin{tabular}{lccll}
\hline $\begin{array}{c}\text { Country } \\
\text { code }\end{array}$ & $\begin{array}{c}\text { Number of } \\
\text { articles }\end{array}$ & $\%$ & Country & \multicolumn{1}{c}{ WHO region } \\
\hline SE & 137 & 0.38 & Sweden & European Region \\
MX & 119 & 0.33 & Mexico & $\begin{array}{l}\text { Region of the } \\
\text { Americas }\end{array}$ \\
NO & 102 & 0.28 & Norway & European Region \\
TR & 94 & 0.26 & Turkey & European Region \\
CO & 89 & 0.25 & Colombia & Region of the \\
& & & & Americas \\
PK & 78 & 0.22 & Pakistan & Eastern Mediterranean \\
& & & & Region \\
NZ & 79 & 0.22 & New Zealand & Western Pacific Region \\
SG & 73 & 0.20 & Singapore & Western Pacific Region \\
\hline
\end{tabular}

\section{Figure 2}

Geographical Distribution of Publications

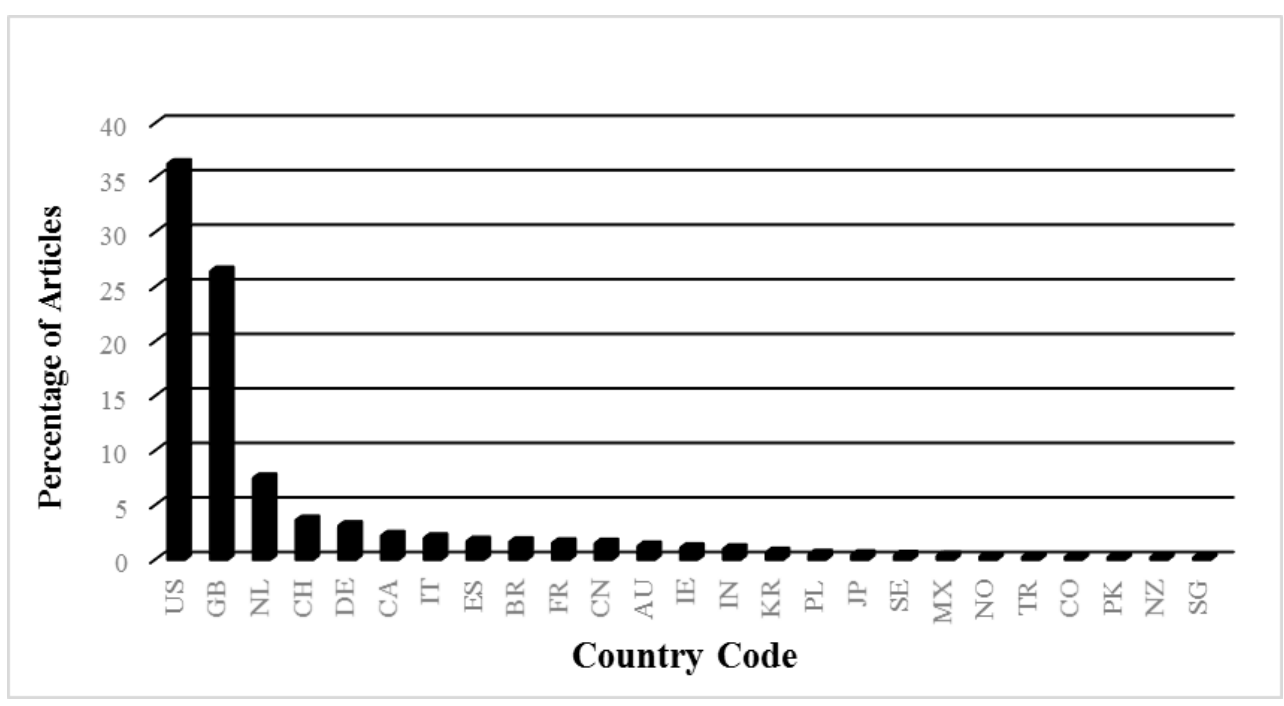




\section{Classification of Type of Study}

Types of studies in Coronavirus infections would potentially open new possibilities for medical professionals to better treat patients and predict what level of hospital care they need. There are various types of research studies, and the choice of study type will mainly depend on the research question. Table 6 shows the classification of the papers published from December 2019 to November 2020, depending on the type of study and design. The study reveals that the maximum number of articles published is related to risk factors 7,198 (20.11\%), whereas 6,189 $(17.29 \%)$ articles are on Prognostic studies. Out of the total 35,791 research articles, 5,671 (15.84\%) articles published diagnostic studies.

\section{Table 6}

Classification by Type of Study and Study Design

\begin{tabular}{|c|c|c|c|c|c|}
\hline Type of study & $\begin{array}{c}\text { Number } \\
\text { of } \\
\text { Articles }\end{array}$ & $\%$ & Type of study & $\begin{array}{c}\text { Number } \\
\text { of } \\
\text { Articles }\end{array}$ & $\%$ \\
\hline Risk factors & 7,198 & 20.11 & Incidence study & 362 & 1.01 \\
\hline Prognostic study & 6,189 & 17.29 & $\begin{array}{l}\text { Patient } \\
\text { preference }\end{array}$ & 249 & 0.70 \\
\hline Diagnostic study & 5,671 & 15.84 & Ethical aspects & 135 & 0.38 \\
\hline Etiology study & 3,852 & 10.76 & $\begin{array}{l}\text { Systematic } \\
\text { review }\end{array}$ & 121 & 0.34 \\
\hline $\begin{array}{l}\text { Observational } \\
\text { study }\end{array}$ & 2,632 & 7.35 & $\begin{array}{l}\text { Evidence } \\
\text { synthesis }\end{array}$ & 97 & 0.27 \\
\hline $\begin{array}{l}\text { Social } \\
\text { Determinants } \\
\text { Health }\end{array}$ & 2,335 & 6.52 & $\begin{array}{l}\text { Equity and } \\
\text { inequality }\end{array}$ & 81 & 0.23 \\
\hline Case report & 1,591 & 4.45 & $\begin{array}{l}\text { Health economic } \\
\text { evaluation }\end{array}$ & 63 & 0.18 \\
\hline $\begin{array}{l}\text { Clinical Practice } \\
\text { Guide }\end{array}$ & 1,262 & 3.53 & Evaluation study & 62 & 0.17 \\
\hline $\begin{array}{l}\text { Qualitative } \\
\text { research }\end{array}$ & 1,176 & 3.29 & Overview & 59 & 0.16 \\
\hline
\end{tabular}




\begin{tabular}{lcclcc} 
Screening study & 969 & 2.71 & $\begin{array}{l}\text { Implementation } \\
\text { research }\end{array}$ & 59 & 0.16 \\
$\begin{array}{l}\text { Controlled clinical } \\
\text { trial }\end{array}$ & 894 & 2.50 & $\begin{array}{l}\text { Systematic } \\
\text { review of } \\
\text { observational } \\
\text { studies }\end{array}$ & 57 & 0.16 \\
Prevalence study & 672 & 1.88 & $\begin{array}{l}\text { Health } \\
\text { technology } \\
\text { assessment }\end{array}$ & 5 & 0.01 \\
\hline
\end{tabular}

\section{Language-wise Distribution of World Coronavirus (COVID-19) Infections Research}

A total of 16 different languages were encountered in retrieved articles, while three are bilingual. English (93.25\%) was the most common, followed by Spanish (2.77\%), Portuguese (1.08\%), and Chinese (1.04\%). Articles written in other languages are shown in Table 7.

\section{Table 7}

Language-wise Distribution of Coronavirus (COVID-19) Research

\begin{tabular}{lccccc}
\hline Language & $\begin{array}{c}\text { Number of } \\
\text { Articles }\end{array}$ & $\%$ & Language & $\begin{array}{c}\text { Number of } \\
\text { Articles }\end{array}$ & \\
\hline English & 33376 & 93.25 & Hungarian & 38 & 0.11 \\
Spanish & 991 & 2.77 & Russian & 23 & 0.06 \\
Portuguese & 386 & 1.08 & Japanese & 7 & 0.02 \\
Chinese & 373 & 1.04 & Turkish & 5 & 0.01 \\
German & 292 & 0.82 & Polish & 3 & 0.01 \\
French & 171 & 0.48 & Greek & 1 & 0.00 \\
Norwegian & 82 & 0.23 & Icelandic & 1 & 0.00 \\
Italian & 41 & 0.11 & Korean & 1 & 0.00 \\
\hline
\end{tabular}




\section{Analysis of Authorship Pattern}

A total number of 74,773 name occurrences was found, denoting the authors contributed to 35,791 publications related to Coronavirus infections from December 2019 to November 2020. The authorship pattern of publications depicts that the single authored papers are $96.11 \%$ of the total, occupying the first place. The next position goes to dual author papers having $2.54 \%$ of the entire research contributions. Three author contributions occupy the third position with $1.11 \%$ of the total publication. It indicates that the multi authored contribution is extremely less than that of the single authored. Most productive authors are based on the number of articles and those who have written more than ten articles. All the articles here are in English and appeared on the MEDLINE database.

Table 8 below shows the most productive authors and percentages of the authors who have written greater than ten articles related to Coronavirus infections during the study. Table 8 denotes the most productive authors who have published their research on Coronavirus infections. Viroj Wiwanitkit is the most productive single author in the domain of Coronavirus infections research with 16 publications, followed by Talha Burki with 15 publications and 14 articles by Smriti Mallapaty. Indian author Viroj Wiwanitkit is the most productive single author, and he has contributed both as single and co-author for 66 articles. Eric J. Rubin, Lindsey R. Baden and Stephen Morrissey have made their highest contribution by writing 34 articles and publishing them in the New England Journal of Medicine. 


\section{Table 8}

Author Productivity with more than 10 Publications

\begin{tabular}{lc}
\hline \multicolumn{1}{c}{ Author } & No of articles \\
\hline Eric J. Rubin, Lindsey R. Baden and Stephen Morrissey & 34 \\
Beuy Joob and VirojWiwanitkit & 27 \\
Viroj Wiwanitkit & 16 \\
Talha Burki & 15 \\
Smriti Mallapaty & 14 \\
Sora Yasri and Viroj Wiwanitkit & 13 \\
Heidi Ledford & 13 \\
Jennifer Abbasi & 12 \\
Jon Cohen & 12 \\
Amy Maxmen & 12 \\
Ewen Callaway & 12 \\
Kai Kupferschmidt & 11 \\
Rita Rubin & 10 \\
Piero Dalerba, Bruce Levin and John L. Thompson & 10 \\
Rujittika Mungmungpuntipantip and Viroj Wiwanitkit & 10 \\
\hline
\end{tabular}

\section{Lotka's Law and Pattern of Author Productivity of Coronavirus Infections Research Output}

Lotka's Law reveals the productivity frequency distribution of authors in a given subject/discipline. In this paper, an attempt has been made to study Lotka's Law's applicability to Coronavirus infections publications. In testing the applicability of the law, the value of 'n', and ' $\mathrm{C}$ ' of the data set has been determined with the help of calculations made in Table 9 shown below. 
Table 9

Author Productivity and Lotka's Law

\begin{tabular}{|c|c|c|c|c|c|}
\hline $\mathrm{S} / \mathrm{N}$ & $\begin{array}{c}\text { Number } \\
\text { of } \\
\text { articles } \\
\left(x_{i}\right)\end{array}$ & $\begin{array}{c}\text { Number } \\
\text { of } \\
\text { authors } \\
\left(y_{i}\right)\end{array}$ & $\begin{array}{c}\text { Observed } \\
\text { percentage } \\
\text { of authors } \\
100 \times\left(\frac{y_{i}}{\sum_{y_{i}}}\right)\end{array}$ & $\begin{array}{c}\text { Expected } \\
\text { Number of } \\
\text { authors } \\
\left(\frac{y_{1}}{x_{i}^{2}}\right)\end{array}$ & $\begin{array}{c}\text { Expected } \\
\text { percentage of } \\
\text { author } \\
\text { predicted by } \\
\text { Lotka }\end{array}$ \\
\hline 1 & 1 & 7,1868 & 96.11 & 7,1868 & 63.00 \\
\hline 2 & 2 & 1,900 & 2.54 & 17,967 & 15.75 \\
\hline 3 & 3 & 827 & 1.11 & 7,985 & 7.00 \\
\hline 4 & 4 & 78 & 0.10 & 4,491 & 3.94 \\
\hline 5 & 5 & 46 & 0.06 & 2,874 & 2.52 \\
\hline 6 & 6 & 20 & 0.03 & 1,996 & 1.75 \\
\hline 7 & 7 & 8 & 0.01 & 1,466 & 1.29 \\
\hline 8 & 8 & 5 & 0.01 & 1,122 & 0.98 \\
\hline 9 & 9 & 2 & 0.00 & 887 & 0.78 \\
\hline 10 & 10 & 3 & 0.00 & 718 & 0.63 \\
\hline 11 & 11 & 1 & 0.00 & 647 & 0.57 \\
\hline 12 & 12 & 4 & 0.01 & 499 & 0.44 \\
\hline 13 & 13 & 3 & 0.00 & 425 & 0.37 \\
\hline 14 & 14 & 1 & 0.00 & 366 & 0.32 \\
\hline 15 & 15 & 1 & 0.00 & 319 & 0.28 \\
\hline 16 & 16 & 1 & 0.00 & 280 & 0.25 \\
\hline 17 & 27 & 2 & 0.00 & 98 & 0.09 \\
\hline 18 & 34 & 3 & 0.00 & 62 & 0.05 \\
\hline & & 74,773 & 100 & 114,070 & 100 \\
\hline
\end{tabular}


Lotka's Law well explains the author productivity, and Table 9 shows the details. According to the Table 9, though, there is a slight variation between the observed percentage of authors and the expected percentage of authors. It is close to conforming to Lotka's Law.

\section{Conclusion}

The widespread COVID-19 epidemic disease has created many challenges and raised severe public health issues for people in almost all countries. It has prompted a demand for global scientific communities to carry out specific medical research that may better characterise this virus, its viral and clinical effects and pathogens, which results in a vast growth of literature on COVID-19 research. This study results reflect the global research output on COVID-19 virus. In the year, December 2019 to November 2020, there have been 35,791 full-text articles published by the researchers.

Moreover, analysis of literature found that the majority of research articles were concerned with the identification of clinical aspect and diagnosis of the disease. The volume of COVID-19 related publications, especially in the biological and medical fields, has increased sharply since January 2020. However, apart from this increase in volume, other changes in scholarly research are also taking place. The present dataset was evaluated through the law of bibliometrics, namely Bradford's Law of scattering and found that it was closely conforming to the law.

Regarding the country of origin of publication, scientists from over 57 countries contributed to COVID-19 publications. America was the largest contributor (36.29\%) of the published articles. UK (26.43\%) and Netherlands $(0.79 \%)$ lagged in second and third place. According to 
the geographical distribution of the publication, European countries have emerged as the most productive. Risk factors of Coronavirus infections have extremely challenged the capacity of the global public healthcare system. The study reveals that the maximum number of articles 7,198 $(20.11 \%)$ were published about risk factors. Out of the papers published in 16 different languages, the English (93.25\%) are unevenly higher than the others.

Spanish (2.77\%) and Portuguese (1.08\%) languages take the second and third places. Greek, Icelandic and Korean languages are on the bottom line with one article each. The highest number of articles are related to aetiology, prognosis, prediction, diagnosis and therapy. The top publication outlets are the International Journal of Environmental Research and Public Health (online), followed by The Lancet, PLoS One and BMJ. The majority of the contributions are single-authored. The highly productive co-authors are J. Eric Rubin, R. Lindsey Baden and Stephen Morrissey, and they contributed with 34 publications, followed by Beuy Joob and Viroj Wiwanitkit contributing to 27 publications. Viroj Wiwanitkit in India contributed with 16 publications as the most productive single author, and he is the most contributed author both in single and co-author publications. According to Lotka's Law there is a variation of author productivity between the observed percentage and expected percentage of authors.

However, it is a must for further scientific researches with contents that can help the global response against this outbreak move forward. The concern of global researchers should shift towards the management of the disease. It shows an exponential rise in the number of research publications on COVID-19 since the outbreak of the pandemic. 
Many researchers in several regions of the world are working towards controlling the spread of COVID-19 infectious diseases.T his scientometric study showcases achievements in Medical research through secondary analysis of published articles and will help the researchers appreciate the previous and ongoing statuses of COVID-19 research efficiently and predict and choose forthcoming advancements and design upcoming research. 


\section{References}

Askew, C. A. (2008). An examination of Lotka's law in the field of library and information studies. [Doctoral thesis. Florida. International University Miami]. https://digitalcommons.fiu.edu/ cgi/viewcontent.cgi?referer=https://www.google.com/\&httpsredir $=1 \&$ article $=1235 \&$ context $=$ etd

Bradford, S. C. (1948). Documentation. Crosby Lockwood.

Brookes, B. C. (1985). Sources of information on specific subjects by S. C. Bradford. Journal of Information Science, 10(4), 176-180. https://doi.org/10.1177/016555158501000406

Coile, R. C. (1978). Lotka's frequency distribution of scientific productivity, center for naval analyses. https://apps.dtic.mil/ $\mathrm{dtic/tr/fulltext/u2/a054425.pdf}$

Darsono, D., Rohmana, J. A., \& Busro, B. (2020). Against COVID-19 pandemic: Bibliometric assessment of world scholars' international publications related to COVID-19. Journal Komunikasi Ikatan Sarjana Komunikasi Indonesia, 5(1), 75-89. https://doi.org/10.25008/jkiski.v5i1.356

Dehghanbanadaki, H., Seif, F., Vahidi, Y., Razi, F., Hashemi, E., Khoshmirsafa, M., \& Aazami, H. (2020). Bibliometric analysis of global scientific research on Coronavirus (COVID-19). Medical Journal of the Islamic Republic of Iran, 34(1), 354-362. https://doi.org/10.34171/mjiri.34.51

Hood, W. W., \& Wilson, C. S. (2001). The literature of bibliometrics, scientometrics, and informetrics. Scientometrics, 52(2), 291-314. https://doi.org/10.1023/A:1017919924342 
Huang, C., Wang, Y., Li, X., Ren, L., Zhao, J., Hu, Y., Zhang, L., Fan, G., Xu, J., Gu, X., Cheng, Z., Yu, T., Xia, J., Wei, Y., Wu, W., Xie, X., Yin, W., Li, H., Liu, M., ... Cao, B. (2020). Clinical features of patients infected with 2019 novel Coronavirus in Wuhan, China. The Lancet, 395, 497-506. https://doi.org/ 10.1016/S0140-6736(20)30183-5

Kambhampati, S. B. S., Vaishya, R., \& Vaish, A. (2020). Unprecedented surge in publications related to COVID-19 in the first three months of pandemic: A bibliometric analytic report. Journal of Clinical Orthopaedics and Trauma, 11(3), 304-306. https://doi.org/10.1016/j.jcot.2020.04.030

Lotka, A. J. (1926). The frequency distribution of scientific productivity. Journal of the Washington Academy of Sciences, 16(12), 317-323.

Lou, J., Tian, S. J., Niu, S. M., Kang, X. Q., Lian, H. X., Zhang, L. X., \& Zhang, J. J. (2020). Coronavirus disease 2019: A bibliometric analysis and review. European Review for Medical and Pharmacological Sciences. 24(6), 3411-3421. https://www.europeanreview.org/article/20712

Medical News Today (2020). Novel Coronavirus: Your questions, answered. https://www.medicalnewstoday.com/articles/novelcoronavirus-your-questions-answered

Nalimov, V. V. \& Mulchenko, B. M. (1969). Scientometrics: Studies of science as a process of information. Nauka.

Rao, I. K. R. (1998). An analysis of Bradford multipliers and a model to explain the law of scattering. Scientometrics, 41(1), 93-100. https://link.springer.com/article/10.1007/BF02457970 
Tao, Z., Zhou, S., Yao, R., Wen, K., Da, W., Meng, Y., Yang, K., Liu, H., \& Tao, L. (2020). COVID-19 will stimulate a new Coronavirus research breakthrough: A 20-year bibliometric analysis. Annals of Translational Medicine, 8(8), 528-528. https://doi.org/10.21037/atm.2020.04.26

Tran, B. X., Nghiem, S., Afoakwah, C., Latkin, C. A., Ha, G. H., Nguyen, T. P., Doan, L. P., Pham, H. Q., Ho, C. S. H. , \& Ho, R. C. M. (2019). Characterisingobesity interventions and treatment for children and youths during 1991-2018. International Journal of Environmental Research and Public Health, 16(21), 4227. https://www.researchgate.net/publication/336824876_Characteriz ing_Obesity_Interventions_and_Treatment_for_Children_and_Yo uths_During_1991-2018

World Health Organization (2020a, May 21). Global research on Coronavirus disease (COVID-19). https://www.who.int/ emergencies/diseases/novel-coronavirus-2019/global-researchonnovel-Coronavirus-2019-ncov

World Health Organization (2020b, May 24). Key messages and actions for COVID-19 prevention and control in chools. https://www.who.int/docs/default-source/coronaviruse/keymessages-and-actions-for-covid-19-prevention-and-control-inschools-march-2020.pdf?sfvrsn=baf81d52_4\#: :text='CO'\% 20stands $\% 20$ for,types $\% 20$ of $\% 20$ common $\% 20$ cold

World Health Organization (2020c, May 22). Naming the Coronavirus disease (COVID-19) and the virus that causes it. https://www.who.int/emergencies/diseases/novel-coronavirus- 
Journal of the University Librarians Association of Sri Lanka, Vol.24, Issue 2, June 2021, 57-87 DOI: http://doi.org/

2019/technical-guidance/naming-the-coronavirus-disease-(covid2019)-and-the-virus-that-causes-it

Worldometer (2020, May 24). Covid-19 Coronavirus pandemic. Retrieved May 24, 2020. https://www.worldometers.info/ coronavirus/ 